\title{
KEPADATAN DAN KEANEKARAGAMAN MEGABENTOS BERDASARKAN PERSENTASE TUTUPAN KARANG DI PERAIRAN DESA BUTON, KECAMATAN BUNGKU SELATAN, KABUPATEN MOROWALI, SULAWESI TENGAH
}

\section{Density and Diversity of Megabenthos Based on Percentage of Coral Cover in Buton Village, Southbungku, Morowali District, Central Sulawesi}

\author{
Messy Bangapadang ${ }^{1}$, Emiyarti $^{2}$, dan Wa Nurgayah ${ }^{3}$ \\ ${ }^{1}$ Mahasiswa Jurusan Ilmu Kelautan, \\ Fakultas Perikanan dan Ilmu Kelautan, Universitas Halu Oleo. \\ Jl. H.E.A Mokodompit Kampus Hijau Bumi Tridharma Anduonohu Kendari 93232, Telp/Fax: (0401) 3193782 \\ ${ }^{2}$ Surel: emiyarti70@gmail.com \\ ${ }^{3}$ Surel: nurgayah_fish@yahoo.com
}

\begin{abstract}
Abstrak
Bulu babi, bintang laut biru, teripang, kima, lola, siput drupella, lobster, dan bintang laut berduri merupakan organisme megabentos yang berasosiasi dengan terumbu karang. Terumbu karang adalah habitat bagi ribuan biota, baik yang hidup sementara maupun menetap selamanya. Penelitian ini bertujuan untuk mengetahui kepadatan dan keanekaragaman megabentos serta untuk mengetahui hubungan persentase tutupan karang dengan kepadatan dan keanekaragaman jenis megabentos di Perairan Desa Buton, Sulawesi Tengah. Penelitian ini dilaksanakan pada bulan Januari-April 2019, yang meliputi pengambilan data dan pengolahan data. Pengambilan data megabentos dilakukan dengan menggunakan metode Belt Transect yang ditarik sejajar garis pantai dengan luasan $150 \mathrm{~m}^{2}$. Untuk pengambilan data persentase tutupan karang menggunakan metode Line Intercept Transect (LIT) dengan menarik transek sejajar garis pantai sepanjang $60 \mathrm{~m}^{2}$. Nilai kepadatan megabentos yang tertinggi dengan nilai $2,37 \mathrm{ind} / \mathrm{m}^{2}$ berada pada kondisi karang yang baik dengan nilai tutupan persentase $73,03 \%$ dan yang terendah dengan nilai $2,13 \mathrm{ind} / \mathrm{m}^{2}$ berada pada kondisi karang yang sedang dengan nilai tutupan persentase 48,32\%. Hasil indeks keanekaragaman jenis megabentos pada kondisi karang yang baik diperoleh 1,73, untuk kategori kondisi karang yang sedang diperoleh nilai 1,59, danuntuk kategori karang yang buruk diperoleh nilai 1,32. Hasil perhitungan korelasi kepadatan megabentos dengan persentase tutupan karang diperoleh nilai $r=0,57$ dengan kategori hubungan sedang, sedangkan untuk hubungan keanekaragaman jenis dengan persentase tutupan karang sangat kuat diperoleh nilai $\mathrm{r}=0,99$.
\end{abstract}

Kata Kunci: Megabentos, Kepadatan, Keanekaragaman, Desa Buton

\begin{abstract}
Sea urchin, blue sea star, sea cucumber, clam, lola, drupella snail, lobster, and spiny sea star are megabenthos associated with coral reefs. Coral reef is a habitat for thousands of biota, both those who live temporarily and permanently. This study aims to determine the density and diversity of megabenthos and to determine the relationship between the percentage of coral cover and the density and diversity of megabenthos species in the Buton Village Waters, Central Sulawesi. This research was conducted in January-April 2019, which included data retrieval and data processing. Megabenthos data retrieval was done using belt transect method which was drawn parallel to the coastline with an area of $150 \mathrm{~m}^{2}$. Collecting coral cover percentage data used Line Intercept Transect (LIT) method by drawing a transect along the coastline along 60 $\mathrm{m}^{2}$. The highest megabenthos density with good coral conditionwas $2,37 \mathrm{ind} . / \mathrm{m}^{2}$ and percentage cover was $73,03 \%$ and the lowest with moderate coral condition was 2,13 ind. $/ \mathrm{m}^{2}$ and percentage cover was $48,32 \%$. The results of the diversity index of megabenthos on good coral category was obtained 1,73 , for the moderate category was obtained 1,59 , and for the bad category was obtained 1,32 . The results of the calculation of the megabenthos density correlation with the percentage of coral cover was obtained $r=0.57$ with a medium relationship category, while for the relationship of species diversity with a very strong percentage of coral cover was obtained $r=0.99$.
\end{abstract}

Keywords: Megabenthos, Density, Diversity, Buton Village

\section{Pendahuluan}

Keanekaragaman hayati yang paling produktif dan paling kaya yaitu terumbu karang sebagai ekosistem yang memiliki peran sangat penting bagi kelangsungan hidup biota laut (Oktarina et al., 2014). Ekosistem terumbu karang merupakan habitat bagi ribuan biota, baik sementara maupun menetap sepanjang hidupnya. Terumbu karang memiliki struktur fisik yang rumit, bercabangcabang dan bergua-gua membuat ekosistem ini menarik bagi banyak jenis biota laut baik flora dan fauna. Salah satu biota yang hidup 
pada ekosistem terumbu karang yaitu megabentos (Tuhumena et al., 2013).

Megabentos merupakan organisme yang berukuran lebih dari $1 \mathrm{~cm}$ yang hidup di atas atau di dalam dasar laut, meliputi biota menempel, merayap dan meliang serta memiliki peran sebagai sumber bahan makanan bagi organisme yang lain. Megabentos terdiri dari beberapa organisme seperti teripang, kima, lobster, lola, bintang laut berduri, siput drupella, bulu babi, dan bintang laut biru (COREMAP LIPI, 2014).

Megabentos dijadikan sebagai indikator pemantauan kondisi kesehatan karang sehingga dibagi menjadi tiga kelompok besar berdasarkan manfaatnya bagi manusia dan ekosistem terumbu karang yaitu echinodermata, moluska dan krustasea. Kelompok pertama, megabentos yang dimanfaatkan oleh manusia yaitu teripang, kima, lobster dan lola. Kelompok kedua yaitu fauna megabentos yang bersifat merugikan terhadap terumbu karang yaitu bintang laut berduri dan siput drupella. Kedua jenis ini memakan polip karang dan koloni karang sehingga populasi hewan ini dapat menyebabkan kerusakan karang yang cukup ekstensif. Sedangkan kelompok ketiga yaitu bulu babi dan bintang laut biru dapat hidup berdampingan dengan terumbu karang tanpa menimbulkan kerugian, tetapi dengan meningkatnya populasi bulu babi akan mempengaruhi terumbu karang yang dapat mengakibatkan kematian karang muda (COREMAP LIPI, 2014).

Perairan Desa Buton merupakan salah satu perairan yang terdapat di Kecamatan Bungku Selatan Kabupaten Morowali, Sulawesi Tengah. Desa ini memiliki keanekaragaman hayati laut sehingga dijadikan sebagai sumber mata pencaharian bagi sebagian besar masyarakat yang umumnya bekerja sebagai nelayan dengan cara menjaring, memancing, dan melakukan penangkapan yang tidak ramah lingkungan yakni aktivitas pengeboman ikan. Adanya kegiatan tersebut dapat menimbulkan dampak bagi biota-biota yang berasosiasi dan dampak terhadap kondisi ekosistem terumbu karang yang ada di Perairan Desa Buton.

Berdasarkan latar belakang tersebut, maka perlunya dilakukan penelitan mengenai kepadatan dan keanekaragaman megabentos pada ekosistem terumbu karang dan hubungan persentase tutupan karang dengan kepadatan dan keanekaragaman megabentos yang terdapat di Perairan Desa Buton, Kecamatan Bungku Selatan, Kabupaten Morowali.

Penelitian ini bertujuan memberikan informasi bagi masyarakat mengenai dampak yang ditimbulkan oleh kegiatan penangkapan yang tidak ramah lingkungan yakni aktivitas pengeboman ikan terhadap biota-biota yang berasosiasi dan terhadap ekosistem terumbu karang, serta menjadi bahan acuan bagi peneliti selanjutnya.

\section{Bahan dan Metode}

Penelitian ini telah dilaksanakan pada bulan Januari - April 2019. Pengambilan data dan sampel, bertempat di Perairan Desa Buton Kecamatan Bungku Selatan, Kabupaten Morowali, Sulawesi Tengah (Gambar 9). Analisa sampel bahan organik tanah (BO), dilakukan di Laboratorium Produktivitas dan Lingkungan Perairan, Fakultas Perikanan dan Ilmu Kelautan Universitas Halu Oleo. Analisa sampel substrat dilakukan di Laboratorium Mekanika Tanah, Fakultas Teknik, Universitas Halu Oleo.

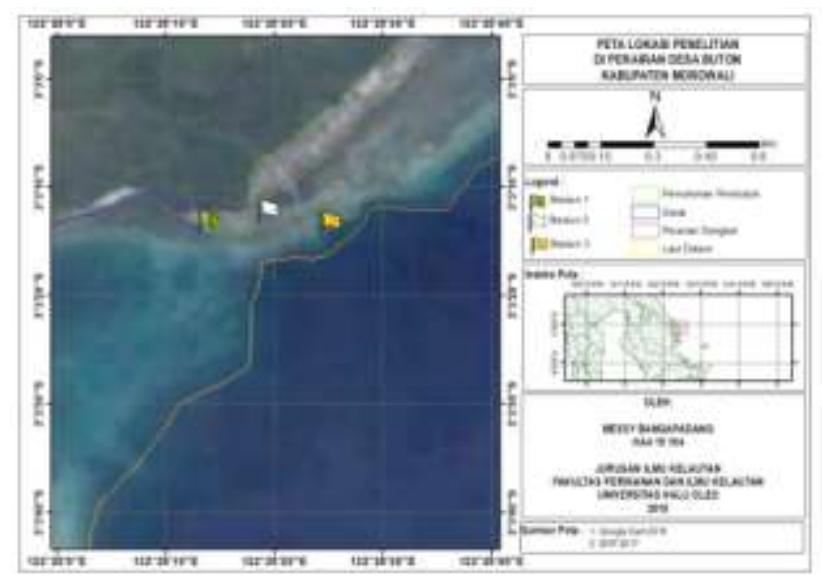

Gambar 9. Peta Lokasi Penelitian 
Tahap survey pendahuluan dilakukan untuk mengetahui kondisi lokasi penelitian, penentuan titik stasiun dalam pengambilan sampel dan persiapan peralatan yang akan digunakan di lapangan. Berdasarkan survey pendahuluan yang telah dilakukan, penentuan titik stasiun menggunakan GPS untuk menandai lokasi penelitian yang diamati. Penentuan tiga titik stasiun yang dipilih dapat mewakili kepadatan dan keanekaragaman megabentos berdasarkan persentase tutupan karang pada Perairan Desa Buton.

Stasiun I : Terletak pada titik koordinat 0303'40,5” LS - 122 $25^{\circ}$ '17,3” BT dimana stasiun ini jauh dari pemukiman dan aktivitas masyarakat. Stasiun II : Terletak pada titik koordinat $03^{\circ} 3^{\prime} 42,1^{\prime \prime}$ LS - $122^{\circ} 25^{\prime} 11,2^{\prime \prime}$ BT, yang berhadapan langsung dengan pemukiman dan merupakan tempat penangkapan masyarakat. Stasiun III : Terletak pada titik koordinat $03^{\circ} 3^{\prime} 38,00^{\prime \prime}$ LS - $122^{\circ} 25^{\prime} 21,8^{\prime \prime}$ BT, berhadapan dengan dermaga dan merupakan tempat bekas pengeboman.

Pengukuran parameter perairan dilakukan untuk mengetahui kondisi perairan tersebut. Pengukuran parameter perairan meliputi pengukuran parameter fisika yaitu suhu, substrat dan kecerahan, serta pengukuran parameter kimia yaitu salinitas, $\mathrm{pH}$, dan BO. Untuk pengukuran parameter biologi yaitu megabentos..

Pengambilan data fauna megabentos dilakukan dengan menggunakan metode belt transect (Munro, 2013), dilakukan dengan cara sebagai berikut:

1. Pengambilan data megabentos pada karang dilakukan dengan menarik garis menggunaka pita berskala (roll meter) sejajar garis pantai dengan panjang $30 \mathrm{~m}$, garis pantai selalu berada di sebelah kiri penyelam sewaktu menarik pita transek dari titik $0 \mathrm{~m}$ sampai $30 \mathrm{~m}$ dengan lebar observasi 2,5 m ke kiri dan kanan garis transek, sehingga luas pemantauan menjadi $150 \quad \mathrm{~m}^{2}$. Pengambilan data dilakukan dengan dua kali pengulangan dengan interval $10 \mathrm{~m}$.

2. Setelah pita transek terpasang, melakukan pengamatan dan pencatatan biota dengan jumlah megabentos yang ada (teripang, kima, lobster, lola, bintang laut berduri, siput Drupella sp., bulu babi, dan bintang laut biru).
Metode yang digunakan dalam pengambilan data tutupan karang adalah LIT (Line Intercept Metode yang digunakan dalam pengambilan data tutupan karang adalah LIT (Line Intercept Transect). Data yang diperoleh adalah persentase tutupan karang. Cara pengambilan data yaitu menarik transek garis dengan menggunakan roll meter yang dibentangkan sejajar garis pantai sepanjang $30 \mathrm{~m}$ dan dilakukan dengan dua kali pengulangan (Saleh, 2009).

\section{Analisis Data}

Kepadatan adalah jumlah individu persatuan luas. Kepadatan masing-masing jenis setiap stasiun dihitung dengan menggunakan rumus Odum (1993), yaitu sebagai berikut:

$D i=\frac{\mathrm{ni}}{\mathrm{A}}$

Keterangan:

$\mathrm{Di}=$ Kepadatan megabentos (ind $/ \mathrm{m}^{2}$ )

ni =Jumlah individu megabentos di tiap stasiun (ind)

$\mathrm{A}=$ Luas daerah pengamatan $\left(\mathrm{m}^{2}\right)$

Perhitungan indeks keanekaragaman megabentos dilakukan dengan menggunakan rumus Odum (1993), yaitu sebagai berikut:

$H^{\prime}=-\sum_{\mathrm{i}=1}^{\mathrm{i}}(\mathrm{Pi} \ln \mathrm{Pi}) ; \mathrm{Pi}=\frac{\mathrm{ni}}{\mathrm{N}}$

Keterangan :

$\mathrm{H}^{\prime}$ = Indeks keanekaragaman

$\mathrm{Pi}=$ Peluang spesies i dari total individu

$\mathrm{S}=$ Jumlah spesies

$\mathrm{ni}=$ Jumlah individu spesies ke-1

$\mathrm{N}=$ Jumlah total individu spesies

Nilai indeks keanekaragaman mempunyai nilai kriteria tertentu yaitu dapat dilihat pada Tabel 2.

Tabel 2. Kriteria Indeks Keanekaragaman (Odum, 1993)

\begin{tabular}{cc}
\hline Kisaran & Keanekaragaman \\
\hline $\mathrm{H}^{\prime}<1$ & Rendah \\
$1<\mathrm{H}^{\prime} \leq 3$ & Sedang \\
$\mathrm{H}^{\prime}>3$ & Tinggi \\
\hline
\end{tabular}

Pengolahan data persentase tutupan karang menggunakan Microsoft Office Excel yang dihitung menggunakan rumus (English et al., 1994) berikut:

$\mathrm{PC}=\frac{\mathrm{Li}}{\text { Ltotal }} \times 100$

Keterangan:

$\mathrm{PC}=$ Persentase tutupan karang $(\%)$

$\mathrm{Li}=$ Panjang tutupan lifeform ke-i $(\mathrm{cm})$

$\mathrm{L}=$ Panjang total tutupan transek $(\mathrm{cm})$ 
Tabel 3. Kategori Persentase Tutupan Karang mengikuti Gomes dan Yap (1984)

\begin{tabular}{cc}
\hline $\begin{array}{c}\text { Persentase } \\
\text { Tutupan } \\
\text { Karang }(\%)\end{array}$ & $\begin{array}{c}\text { Kondisi terumbu } \\
\text { Karang }\end{array}$ \\
\hline $0-24,9$ & Buruk \\
$25-49,9$ & Sedang \\
$50-74,9$ & Baik \\
$75-100$ & Baik Sekali \\
\hline
\end{tabular}

Analisis ukuran butir substrat dilakukan dengan metode saringan bertingkat menggunakan skala Wenworth (Hutabarat dan Evans, 2000).

Tabel 4. Skala Wenworth untuk mengklasifikasikan partikel-partikel Sedimen (Hutabarat dan Evans, 2000)

\begin{tabular}{cc}
\hline Ukuran $(\mathbf{m m})$ & Keterangan \\
\hline$>256$ & Kerakal \\
$2-256$ & Kerikil \\
$1-2$ & Pasir Sangat Kasar \\
$0,5-1$ & Pasir Kasar \\
$0,25-1$ & Pasir Agak Kasar \\
$0,125-0,25$ & Pasir Halus \\
$0,0625-0,125$ & Pasir Sangat Halus \\
$0,0039-0,00625$ & Lanau \\
$<0,0039$ & Lempung \\
\hline
\end{tabular}

Pengolahan analisis hubungan persentase tututpan karang dengan kepadatan dan keanekargaman megabentos menggunakan rumus Sugiyono (2007) sebagai berikut:

$r=\frac{\mathrm{N} \Sigma \mathrm{XY}-(\Sigma \mathrm{X})(\Sigma \mathrm{Y})}{\sqrt{\mathrm{N} \Sigma \mathrm{X}^{2}-\left(\sum \Sigma \mathrm{X}\right)^{2}\left(\mathrm{~N} \Sigma \mathrm{Y}^{2}-\left(\Sigma \mathrm{Y}^{2}\right)\right)}}$

Keterangan :

$\mathrm{r}=$ koefisien korelasi

$\mathrm{X}=$ Variabel yang diukur

$\mathrm{N}=$ Jumlah total sampel

$\mathrm{Y}=$ Variabel yang diukur

Hasil yang diperoleh disesuaikan dengan pedoman interpretasi terhadap koefisien korelasi menurut Sugiyono (2007) disajikan pada Tabel 5.

Tabel 5. Kriteria Koefisien Korelasi

\begin{tabular}{cc}
\hline $\begin{array}{c}\text { Interval } \\
\text { Koefisen }\end{array}$ & $\begin{array}{c}\text { Tingkat } \\
\text { Hubungan }\end{array}$ \\
\hline $0,00-0,199$ & Sangat rendah \\
$0,20-0,399$ & Rendah \\
$0,40-0,599$ & Sedang \\
$0,60-0,799$ & Kuat \\
$0.80-1,00$ & Sangat Kuat \\
\hline
\end{tabular}

\section{Hasil dan Pembahasan}

Kepadatan megabentos sangat dipengaruhi oleh keadaan dan kondisi lingkungan karena jika kepadatan megabentos tinggi maka lingkungan tempat hidupnya itu sesuai, tetapi jika sebaliknya kepadatan megabentos rendah maka kondisi lingkungan tersebut tidak sesuai dengan kelangsungan hidup megabentos.

Tabel 6. Kepadatan Jenis Megabentos pada Lokasi Penelitian

\begin{tabular}{cc}
\hline Stasiun & $\begin{array}{c}\text { Kepadatan Jenis } \\
\text { Megabentos (ind// } \mathbf{m}^{\mathbf{2}} \text { ) }\end{array}$ \\
\hline I & 2,37 \\
II & 2,13 \\
III & 2,22 \\
\hline
\end{tabular}

Tingginya kepadatan megabentos yang terdapat di stasiun I dipengaruhi oleh kondisi terumbu karang yang baik dengan persentase tutupan karang yang termasuk dalam kategori tinggi/baik sehingga stasiun I merupakan habitat yang sesuai dengan keberlangsungan hidup dari megabentos yang berasosiasi di dalamnya. Hal ini sesuai dengan penelitian Dahlan (2014) yang menyatakan kehadiran megabentos dalam keanekaraga-man jenis yang tinggi dapat dipengaruhi oleh kondisi atau kualitas ekosistem terumbu karang yang artinya bahwa semakin baik kondisi terumbu karang maka semakin besar peluang tingginya keanekaragaman megabentos, begitu juga sebaliknya.

Tabel 7. Persentase Tutupan Karang Hidup pada Lokasi Penelitian

\begin{tabular}{cccc}
\hline Kategori & Stasiun I & Stasiun II & Stasiun III \\
\hline Life Coral & 73,03 & 48,32 & 15,68 \\
DC & 5,22 & 22,62 & 37,17 \\
Abiotik & 5,58 & 27,28 & 36,52 \\
Others Biotik & 16,17 & 1,78 & 10,63 \\
\hline
\end{tabular}


Tabel 8. Jenis Megabentos yang ditemukan pada Lokasi Penelitian

\begin{tabular}{|c|c|c|c|c|}
\hline \multirow[b]{2}{*}{ Stasiun } & \multirow[b]{2}{*}{$\begin{array}{c}\text { Jenis } \\
\text { Megabentos }\end{array}$} & \multicolumn{3}{|c|}{ Keterangan } \\
\hline & & $\begin{array}{c}\text { Dimanfaatkan } \\
\text { Manusia }\end{array}$ & $\begin{array}{c}\text { Berdampak Negatif } \\
\text { pada Terumbu } \\
\text { Karang }\end{array}$ & $\begin{array}{c}\text { Tidak Berpengaruh pada } \\
\text { Terumbu Karang }\end{array}$ \\
\hline \multirow{10}{*}{ I } & L. laevigata & - & - & $\checkmark$ \\
\hline & T. niloticus & $\checkmark$ & - & - \\
\hline & A. planci & - & $\checkmark$ & - \\
\hline & T. squamosa & $\checkmark$ & - & - \\
\hline & T. maxima & $\checkmark$ & - & - \\
\hline & T. crocea & $\checkmark$ & - & - \\
\hline & E. calamaris & - & - & $\checkmark$ \\
\hline & D. sitosum & - & - & $\checkmark$ \\
\hline & S. variegates & $\checkmark$ & - & - \\
\hline & P. versicolor & $\checkmark$ & - & - \\
\hline \multirow{7}{*}{ II } & L. laevigata & - & - & $\checkmark$ \\
\hline & T. niloticus & $\checkmark$ & - & - \\
\hline & A. planci & - & $\checkmark$ & - \\
\hline & T. squamosa & $\checkmark$ & - & - \\
\hline & T. maxima & $\checkmark$ & - & - \\
\hline & E. calamaris & - & - & $\checkmark$ \\
\hline & D. sitosum & - & - & $\checkmark$ \\
\hline \multirow{7}{*}{ III } & L. laevigata & - & - & $\checkmark$ \\
\hline & T. niloticus & $\checkmark$ & - & - \\
\hline & A. planci & - & $\checkmark$ & - \\
\hline & T. squamosa & $\checkmark$ & - & - \\
\hline & T. maxima & $\checkmark$ & - & - \\
\hline & E. calamaris & - & - & $\checkmark$ \\
\hline & D. sitosum & - & - & $\checkmark$ \\
\hline
\end{tabular}

Pada stasiun I di dominasi oleh $L$. laevigata, $T$. maxima, dan $D$. sitosum. Kepadatan bulu babi pada stasiun ini dipengaruhi oleh substrat yang beragam dan kondisi lingkungannya yang sesuai. Hal ini sesuai dengan pernyataan Wulandewi et al., (2015) yang menyatakan bahwa faktor yang mempengaruhi tinggi rendahnya densitas bulu babi di suatu Perairan yaitu, ketersediaan makanan dan lingkungan yang sesuai. Tingginya kepadatan megabentos seperti $T$. maxima, L. laevigata, calamaris, dipengaruhi oleh kondisi lingkungan yang baik dan lebih jauh dari jangkauan masyarakat. Hal ini sesuai dengan penelitian Saputra (2016) yaitu kenaekaragaman jenis yang rendah pada lokasi penelitian Pulau Berhala juga dipengaruhi oleh adanya penangkapan jenis kima lainnya yang lebih potensial sehingga hanya ada tersisa jenis kima yang dianggap kurang memiliki nilai ekonomis.

Rendahnya kepadatan megabentos pada stasiun II dan III dipengaruhi oleh beberapa faktor yaitu kondisi terumbu karang, dekat dengan pemukiman masyarakat dan adanya kegiatan penangkapan yang tidak ramah lingkungan (membom) sehingga sangat berpengaruh terhadap kelangsungan hidup megabentos. megabentos yang menjadi buruan masyarakat seperti T. maxima, T. squamosa dan $T$. niloticus karena memiliki nilai ekonomis. Stasiun II banyak ditemukan $A$. planci yang sangat berpotensi sebagai predator terumbu karang sehingga A. planci tidak hanya berasosiasi dengan satu genus karang saja bahkan banyak juga ditemukan pada karang mati akibat di mangsa oleh $A$. planci itu sendiri. Hal ini sesuai dengan penelitian Alustco (2009) yang menyatakan bahwa $A$. planci banyak ditemukan pada genus Acropora Branching dimana tercatat 14 ind/0,5 ha, hanya ditemukan pada genus lainnya dari katgori non-Acropora seperti coral Encrusting (CE), coral Foliose (CF) dan kelompok karang dari genus coral submassive (CS) dan massive. 
Keberadaan megabentos juga dipengaruhi oleh faktor lingkungan seperti kedalaman dan kecerahan perairan. Kecerahan pada stasiun I sampai III masih jernih nilai $100 \%$ dengan kedalaman yang 3 m. Kondisi Perairan Desa Buton masih ditembus oleh cahaya matahari sehingga sangat membantu proses fotosintesis di perairan dan dengan mudah megabentos dapat memperoleh makanan. Hal ini sesuai dengan pernyataan Nuriyah et al., (2010) yang menyatakan bahwa kecerahan perairan adalah kemampuan cahaya menembus lapisan kedalaman tertentu sehingga kecerahan menjadi faktor penting bagi proses fotosintesis dan produksi primer pada perairan.

Tabel 9. Indeks Keanekaragaman Jenis (H') Megabentos pada Lokasi Penelitian

\begin{tabular}{ccc}
\hline Stasiun & H' & Kategori H' \\
\hline I & 1,73 & Sedang \\
II & 1,59 & Sedang \\
III & 1,32 & Sedang \\
\hline
\end{tabular}

Megabentos di Perairan Desa Buton memiliki nilai indeks keanekaragaman jenis yang tidak jauh berbeda pada setiap stasiun dan tergolong dalam kategori sedang (Tabel 8). Tinggi rendahnya indeks keanekaragaman disebabkan oleh faktor lingkungan seperti substrat atau tempat hidupnya megabentos. Substrat yang ditemukan melalui analisis saringan bertingkat diperoleh hasil di setiap stasiun substrat kerikil, pasir sangat kasar dan pasir sangat halus dan kandungan bahan organik yang paling tinggi ada pada stasiun II yaitu $2,12 \mathrm{mg} / \mathrm{L}$, ini dikarenakan stasiun II dekat dengan pemukiman masyarakat sehingga dipengaruhi oleh limbah RT. Sedangkan pada stasiun III kandungan bahan organik yaitu $1,53 \mathrm{mg} / \mathrm{L}$ disebabkan juga oleh banyaknya patahan-patahan karang atau jasad renik biota-biota lain karena stasiun ini merupakan bekas tempat penangkapan ikan yang tidak ramah lingkungan (membom). Pada stasiun I kandungan bahan organik paling rendah karena jauh dari pemukiman dan kondisi terumbu karang yang masih baik. Selain itu juga dipengaruhi oleh kondisi terumbu karang dimana jika kondisi terumbu karang memiliki persentase tutupan yang baik maka jenis biota megabentos akan meningkat begitupun sebaliknya jika kondisi terumbu karang dalam kategori sedang ataupun sudah rusak maka biota megabentos akan menurun.

Pada stasiun I indeks keanekaragamannya tinggi karena tutupan persentase karangnya juga tergolong dalam kategori baik sedangkan pada stasiun II indeks keanekargaman rendah dibanding stasiun I karena kondisi karang tergolong sedang dan stasiun III paling rendah karena kondisi terumbu karangnya tergolong rusak. Hal ini sesuai dengan pernyataan Riza (2016) yang menyatakan terumbu karang tidak terlepas dari peranan ekologisnya sebagai daerah pemijahan (spawning ground), tempat pengasuhan (nursery ground), tempat mencari makan (feeding ground), dan daerah pembesaran (rearing ground) bagi biota ekonomis penting.

Faktor lingkungan seperti fisika dan kimia sangat berpengaruh terhadap perkembangan megabentos seperti salinitas, $\mathrm{pH}$, dan kecepatan arus. Perairan Desa Buton memiliki kisaran $\mathrm{pH}$ 7-7,5 yang menandakan bahwa kondisi perairan netral sehingga masih dapat membantu perkembangan megabentos. Hal ini sesuai dengan pernyataan Simanjuntak (2012) yang menyatakan bahwa $\mathrm{pH}$ merupakan salah satu parameter yang penting dalam memantau kestabilan perairan. Perubahan nilai $\mathrm{pH}$ di suatu perairan akan mempengaruhi kehidupan biota, karena tiap biota memiliki batasan tertentu terhadap nilai $\mathrm{pH}$ yang bervariasi. Hasil penelitian menunjukkan kecepatan arus berkisar0,07-0,11 m/s dan salinitas $35 \%$ o. Hasil menunjukkan masih menunjang kehidupan organisme megabentos. Hal ini sesuai dengan pernyataan Gede et al., (2017) yang menyatakan bahwa arus memegang peranan penting dalam pergerakan zat hara di perairan dan pemanfaatan pergerakan arus oleh biota adalah sebagai alat penggerak terutama biota yang bukan perenang kuat seperti plankton selain itu peranan arus lainnya adalah menyuplai makanan. Selanjutnya Souhoka (2013) menyatakan bahwa salinitas yang baik untuk pertumbuhan dan perkembangan karang dengan batas salinitas tertentu yaitu antara $25-40 \%$ dan masih baik untuk kehidupan organisme laut seperti megabentos. 
Tabel 10. Parameter Kulaitas Perairan

\begin{tabular}{cccccccc}
\hline Stasiun & $\begin{array}{c}\text { Suhu } \\
\left({ }^{\mathbf{C}} \mathbf{C}\right)\end{array}$ & $\begin{array}{c}\text { Kedalaman } \\
(\mathbf{m})\end{array}$ & $\begin{array}{c}\text { Kecerahan } \\
(\mathbf{\%})\end{array}$ & $\begin{array}{c}\text { Salinitas } \\
(\mathbf{p p t})\end{array}$ & $\begin{array}{c}\text { Kecepatan arus } \\
(\mathbf{m} / \mathbf{s})\end{array}$ & $\mathbf{p H}$ & BO $\mathbf{~ m g} / \mathbf{L}$ \\
\hline I & 32 & 3 & 100 & 35 & 0,07 & 7 & 1,14 \\
II & 32 & 3 & 100 & 35 & 0,09 & 7 & 2,12 \\
III & 31 & 3 & 100 & 35 & 0,11 & 7,5 & 1,53 \\
\hline
\end{tabular}

Biota drupella tidak ditemukan di lokasi penelitian, hal ini diduga dipengaruhi oleh faktor Biota drupella tidak ditemukan di lokasi penelitian, hal ini diduga dipengaruhi oleh faktor lingkungan yaitu suhu. Suhu pada Perairan Desa Buton yaitu dari $31^{\circ}-32^{0} \mathrm{C}$ dan masih normal untuk pertumbuhan karang. Berdasarkan penelitian Tarzan (2016), pengaruh perubahan suhu menyebabkan perbedaan komposisi dan kelimpahan Gastropoda, bahkan keberadaan suhu terhadap komunitas cenderung dapat menjadi faktor pembatas bagi beberapa fungsi biologis dari Gastropoda. Kenaikan suhu 4-6 ${ }^{\circ} \mathrm{C}$ dapat menimbulkan kehancuran suatu komunitas.

Biota lobster yang ditemukan di Perairan Desa Buton dengan jenis $P$. versicolor (lobster bambu) sangat rendah karena biota bentos ini merupakan biota yang diburu oleh masyarakat selain untuk diperjualbelikan juga untuk dikonsumsi secara langsung. Lobster memiliki nilai harga jual yang cukup tinggi di pasaran yakni mulai dari harga ribuan perekor sampai jutaan perkilogramnya sehingga tidak heran biota ini menjadi buruan masyarakat. Hal ini sesuai dengan pernyataan Saputra (2009) yang menyatakan bahwa lobster merupakan komoditas ekspor, yang banyak tertangkap di Perairan Kebumen, dengan nilai ekonomis yang tinggi. Oleh karenanya eksploitasi terhadap lobster cenderung meningkat, yang apabila tidak dikendalikan dapat mengarah pada lebih tangkap. Konotasi lebih tangkap umumnya selalu hanya dikaitkan dengan adanya penangkapan yang sangat intensif, sehingga volume yang ditangkap melebihi batas-batas produksi lestarinya.

Hasil analisis koefisien determinansi antara persentase tutupan karang hidup berdasarkan kondisi terumbu karang yang baik, sedang dan buruk dengan kepadatan megabentos, menunjukan bahwa persentase tutupan karang hidup memberi pengaruh terhadap kepadatan megabentos sebesar $32,40 \%$. Berdasarkan hasil yang diperoleh hubungan persentase tutupan karang dengan kepadatan megabentos dengan nilai korelasi antara persentase tutupan karang dengan kepadatan megabentos diperoleh tingkat hubungan yang sedang yang berarti bahwa hasil persentase tutupan karang tidak memberikan pengaruh yang signifikan terhadap tingkat kepadatan megabentos. Hal ini dikarenakan megabentos dapat hidup bukan hanya pada persentase karang yang tinggi namun dapat juga hidup pada persentase karang yang rendah selama kualitas perairan tersebut mampu mendukung proses kelangsungan hidup megabentos. Pada hasil penelitian yang dilakukan ditemukan beberapa spesies megabentos yang menjadi indikator kesehatan dan kerusakan terumbu karang. Hal ini sesuai dengan pernyataan Matsuura et al., (2000) yang menyatakan bahwa megabentos target merupakan biota yang memiliki nilai ekonomis tinggi dan memiliki peran penting terhadap kesehatan karang yang terdiri dari tujuh kelompok biota megabentos indikator.

Sedangkan hubungan persentase tutupan karang dengan keanekaragaman jenis megabentos sangat kuat dengan hasil analisis koefisien determinasi antara persentase tutupan karang hidup dengan keanekaragaman jenis megabentos diperoleh nilai sebesar $99 \%$ yang menunjukan bahwa variabel bebas yakni persentase tutupan karang hidup memberi pengaruh terhadap variabel terikat yakni keanekaragaman jenis megabentos. Nilai ini juga menunjukan penambahan persentase tutupan karang hidup diikuti dengan peningkatan keanekaragaman jenis megabentos. Megabentos jenis teripang, kima, lola dan lobster yang ditemukan pada lokasi penelitian merupakan biota-biota ekonomis penting yang hidup di ekosistem terumbu karang. Kehadirannya pada ekosistem terumbu karang merupakan indikator bahwa karang di lokasi tersebut masih sehat. Jika karang di lokasi tersebut telah mengalami kerusakan, kondisi fisika-kimia perairan cukup mendukung kehidupan ketiga spesies tersebut. Hal ini sesuai dengan pernyataan 
COREMAP LIPI, (2014) yang menyatakan jenis-jenis megabentos yang secara umum dimanfaatkan oleh masyarakat, yaitu teripang, kima, lobster dan lola. Selain daripada itu, di lokasi penelitian juga ditemukan A. planci dimana jenis megabentos ini memiliki hubungan yang tidak baik dengan terumbu karang karena jenis megabetos ini menjadi predator polip karang dengan memakan jaringan hidup dari karang keras sehingga menyebabkan kematian bagi koloni karang. Hal ini sesuai dengan pernyataan Mauliza et al., (2016) yang menyatakan bahwa kepadatan populasi $A$. planci di daerah terumbu karang akan memberikan dampak negatif bagi kehidupan karang.

Jenis megabentos yang mendominasi dari ketiga stasiun pada lokasi penelitian yaitu L. laevigata dan $D$. sitosum sebagai salah satu kelompok dari echinodermata yang dipilih sebagai indikator karena kehadirannya hampir disetiap terumbu karang. Menurut Giyanto et al., (2014) yang menyatakan bahwa kehadiran organisme ini sebagai objek yang tidak di manfaatkan oleh masyarakat dan tidak pula merugikan terumbu karang, menjadikannya biota yang diharapkan dapat memberi informasi mengenai kondisi terumbu karang. Beberapa penelitian menunjukkan bahwa terjadinya ledakan populasi $D$. sitosum dalam satu kawasan dapat dikaitkan sebagai deteksi adanya zat pencemar dalam kawasan tersebut. Fungsi lain dari D. sitosum pada ekosistem terumbu karang yaitu untuk membersihkan algae yang tumbuh pada karang mati yang telah ditumbuhi algae, sesuai dengan sifatnya dalam mencari makan sebagai algae feeder. Kehadiran D. sitosum ini memiliki peran yang menguntungkan bagi ekosistem terumbu karang karena turut membersihkan algae, sehingga memungkinkan karang untuk tumbuh dengan baik setelah substrat dibersihkan oleh bulu babi dari keberadaan algae. Hal ini didukung oleh pernyataan Azis (1996) menyatakan bahwa bulu babi dapat hidup pada substrat yang keras yaitu pada karang hidup, karang mati ataupun pecahan karang.

\section{Simpulan}

Berdasarkan hasil penelitian yang telah dilakukan maka dapat ditarik kesimpalan bahwa:

1. Kepadatan megabentos yang tertinggi berada pada persentase tutupan karang yang baik dengan nilai $2,37 \mathrm{ind} / \mathrm{m}^{2}$ dan yang paling rendah berada pada persentase tutupan karang dengan kategori sedang.

2. Hubungan persentase tutupan karang dengan kepadatan dan keanekaragaman jenis megabentos yaitu semakin tinggi tutupan karang maka semakin tinggi juga kepadatan dan keanekaragaman jenis megabentos.

\section{Daftar Pustaka}

Alustco S. 2009. Kajian Kualitas Tutupan Karang Hidup dan kaitannya dengan Achancaster Planci di Kabupaten Bintan.

Aziz, A. 1996. Makanan dan Cara Makan Berbagai Jenis Bulu Babi Jilid - 2. Osena 12(4): $91-100$.

COREMAP II LIPI. 2014. Panduan Monitoring KesehatanTerumbuKarang

Dahlan. 2014. Penilaian Ekosistem Terumbu Karang Di Kepulauan Aruri Kabupaten Supiori. The Journal of Fisheries Development. Vol. 1(1) : 61-82.

English, S., C. Wilkinson and V. Baker. 1994. Survey manual for tropical marine resources. - Australia Institute of Marine Science. Townsville, $368 \mathrm{pp}$.

Giyanto, A. E.W., Manuputty, M., Abrar, R. M., Siringoringo, S. R., Suharti K. W., Nagib, I. E., Ucu, Y., Arbi, H. A. W., Cappenberg, H.F., Sihaloho, Y., Tuti dan Anita, D. Z. 2014. Panduan Monitoring Kesehatan Karang. COREMAP-CTI LIPI. Hal. 33-36.

Gomez, E. D. and H. Yap. 1984. Monitoring Reef Condition. Dalam Kenchington, R.A. and B. Hudson E.T. (ed). Coral Reef Management Hand Book. Unesco Regional Office for Science and Technology for South East Asia. Jakarta, 187-195 pp.

Hernandez J.C., Brito A. N., Garcia M. C., Gil-Rodriguez G., Herrera A. C. Reyes J.M., Falcon. 2006. Spatial and seasonal variation of the gonad index of Diademaantillarum

(Echinodermata:Echinoidea) in the Canary Islands. Scientia Marina. Vol. 70(4).

Hutabarat dan Evans. 2000. Pengantar Oseanografi. Universitas Indonesia Press Jakarta. 
Jaluddin dan Ardeslan. 2017. Identifikasi dan Klasifikasi Phylum Echinodermata Di Perairan Laut Desa Sembilan Kecamatan Simeulue Barat Kabupaten Simeulue. Jurnal Biology Education. Vol. 6(1).

Matsuura, K., Sumadhiharga, O. K., Tsukamoto, K. 2000. Field Guide to Lombok Island. Identification Guide to Marine Organisms in Seagrass Beds of Lombok Island, Indonesia. University of Tokyo, Tokyo.

Mauliza R., Prihadi D. J., dan Syamsuddin M . L. 2016. Keterkaitan Kepadatan Predator Karang Bintang Laut Berduri (Acanthaster Planci) Terhadap Kondisi Terumbu Karang Di Perairan Pulau Batu Malang Penyu, Kepulauan Belitung. Jurnal Perikanan Kelautan Vol. 7(2) : 58-64.

Munro, C. (2013) Diving. Methods for the Study of Marine Benthos (ed. by A. Eleftheriou), pp.125-173. John Wiley \& Sons, Ltd.

Nuriya H., Hidayah Z., Syah A. F. 2010. Analisis Parameter Fisika Kimia di Perairan Sumenep Bagian Timur dengan Menggunakan Citra Landsat TM 5. Jurnal Kelautan. Vol. 3(2).

Odum E. P. 1993. Dasar-dasar Ekologi. Terjemahan Tjahjono Samingan. Edisi Ketiga Yogyakarta : Gajah Mada University Press.

Oktarina A., Kamal E., Suparno. 2014. Kajian KondisiTerumbu Karang dan Straegi Pengelolaannya di Pulau Panjang, Air Bangis, Kabupaten Pasaman Barat. Jurnal Natur Indonesia. Vol. 16(1) : 2331.

Riza S. 2016. Tingkat Tutupan Ekosistem Terumbu Karang Di Perairan Pulau Terkulai.

Saleh. 2009. Teknik Pengukuran dan Analisis Kondisi Ekosistem Terumbu Karang.www.coremap.or.id. Diakses pada [16/06/2016].

Saputra A. 2016. Pola Sebaran Kima Di Perairan Laut Pulau Berhala Kecamatan Jemaja Kabupaten Kepulauan Anambas Provinsi Kepulauan Riau.

Saputra, W. S. 2009. Status Pemanfaatan Lobster (Panulirus sp) di Perairan Kebumen. Jurnal Saintek Perikanan Vol. 4, No. 2: 10 - 15.
Simanjuntak M. Dan Kamlasi Y. 2012. Sebaran Horizontal Zat Hara di Perairan Lamalera, Nusa Tenggara Timur. Ilmu Kelautan.Vol. 17 (2) 99108.

Souhoka, J., Patty S. 2013. Pemantauan Kondisi Hidrologi Dalam Kaitannya Dengan Kondisi Terumbu Karang Di Perairan Pulau Talise, Sulawesi Utara. Jurnal Ilmiah. Vol. 1:(3).

Sugiyono. 2007. Metode Penelitian Administasi. Bandung : Alfabeta.

Tarzan. 2016. Laju Predasi Drupella Cornus (Roding,1798) Pada Beberapa Jenis Karang Acropora Di Hatchery Pulau Barranglompo.

Tuhumena J. R., Kusen J. D., Paruntu C. P. 2013. Struktur Komunitas Karang dan Biota Asosiasi Pada Kawasan Terumbu Karang di Perairan Desa Minanga Kecamatan Malayang II dan Desa Mokupa Kecamatan Tombariri. Jurnal Pesisir dan Laut Tropis. Vol. 3(1).

Wulandewi, N. L. E., Subagio, J. N., \& Wiryatno, J. 2015. Jenis dan Densitas Bulu Babi (Echinoidea) Di Kawasan Pantai Sanur dan Serangan Denpasar Bali.SIMBIOSIS Journal of Biological Sciences, 3(1), 269- 280. 